\title{
BEETLES ASSOCIATED WITH THE MOUND- BUILDING ANT, FORMICA ULKEI EMERY
}

\author{
By ORLANDO PARK
}

\section{Northwestern University}

The mound-building ant, Formica ulkei Emery, has been reported as far west as South Dakota to Nova Scotia and New Brunswick (Wheeler, 1926; Holmquist, 1928). It is recorded from Wisconsin (Burrill and Smith, 1918) and Illinois, and is apparently abundant in northern Ohio $^{1}$ where its range merges with that of the eastern mound-builder, Formica exsectoides.

In Illinois ulkei is at present known only from the Chicago Area where it is well established in two localities (Palos Park and Palatine). In both places the numerous mounds, varying from young nests of less than a foot in diameter up to old hills more than four feet across, are found within the upland oak-ash-hickory forests, where they tend to follow the forest margins and clearings.

These ant mounds present an infinite array of problems which remained uninvestigated until 1926. Since then, a literature upon these Illinois mounds has steadily accumulated, including the life history and behavior of the host ant (Holmquist, 1928a), hibernation (Holmquist, 1928b; Dreyer, 1932), distribution of the nests (Dreyer and T. Park, 1933), and the species of arthropods associated with the host ant (Park, O., 1929; Park, T., 1929).

Among the numerous arthropods associated with ants the myrmecocolous beetles are numerous, both in species and individuals. Many of these beetles are nest scavengers,

${ }^{1}$ I am indebted to Dr. C. H. Kennedy for personal communication upon the Ohio distribution of Formica ulkei and exsectoides. The latter species is reported from Iowa (Wickham, 1900) and Indiana (Blatchley, 1910) so that the actual distribution of these two closely allied ants can not be certainly known until a carefully planned survey can be made. Both ulkei and exsectoides are present in the Chicago Area, however; a small mound was investigated, and workers preserved, near Smith, Indiana on August 27, 1934. These ants I sent to Dr. M. R. Smith who determined them as Formica exsectoides. 
but the majority probably strike at the vitality of the society by feeding upon the host brood. The ant brood appears to be especially stimulating and may be infrequently raided by species which may or may not live in the nest (Park, 1933a), attacked by tolerated nest predators (Park, 1932b), or assiduously licked or devoured by highly specialized commensals and temporary ectoparasites (Park, 1932a, 1933b).

In the following table the beetles associated with Formica ulkei are listed with their seasonal range as far as known for the nests, and authority for the data.

From the above table we find that ten families and fifteen species of beetles have been reported from nests of $F$. ulkei, fourteen of which have been recorded from the Illinois mounds. In passing, mention should be made of the activity of these beetles during the last three weeks of May. Individuals were especially numerous during this period; two species, Atheta polita and Batrisodes globosus made repeated short flights of several inches on the evenings of May 12 and 13, and the syrphid flies of the genus Microdon ${ }^{3}$ pupated on the mornings of May 17 and 18. This seasonal activity is in general agreement with the maximum appearance of species and individuals of Coleoptera in the Chicago area (Park, 1930), as well as that of isolated or specialized communities, e. g. beetle population of fungi (Park, 1931).

Formica ulkei and $F$. exsectoides are not only related taxonomically, but ecologically they are very similar and it is interesting to observe identity of some, and ecological equivalence of other, myrmecocoles from the mounds of these two species of hosts. The following table (Table II) lists those species said to occur in the exsectoides nests as far as I have been able to ascertain from the literature.

So far, no true guest (symphile) has been reported from either Formica ulkei or exsectoides nests. A comparison of tables I and II shows that three species, Tachyura incurva, Megastilicus formicarius, and Hetærius brunneipennis, are common to both host ants, and the species of

${ }^{3}$ These flies are at present being determined, and the data concerning their behavior in the nest, and pupation data are to be given later. 
TABLE I

Coleoptera associated with Formica ulkei

Family

Carabidæ..... Tachyura

(Say)

Clivinia

bipustulata.... (Fab.)

Amara

polita LeC.....

Harpalus

pleuriticus.... February 24 . . . Holmquist, 1928

Kirby

Leptinidæ..... Leptinus

testaceus...... October 6..... Park, O., 1929

Mueller

Staphylinidæ... Gastrolobium

bicolor........ May 7 to

(Graves)

Atheta polita....

Melsh.

Megastilicus formicarius....

Casey

Pselaphidæ.... Batrisodes

globosus.

(LeC.)

Histeridæ. . . . . Hetærius

brunneipennis. May 7....... Present report Rand.

Cucujidæ..... Cathartus

advena........ October 6..... Park, O., 1929

Phalacridæ..... Stilbus (Walt.)

probatus..... September 13

Elateridæ..... Melanotus

communis..... August 6...... Park, O., 1929

Scarabæidæ... Phyllophaga

horni........ October 6..... Park, O., 1929

Smith

Chrysomelidæ.. Coscinoptera

dominicana.... Wisconsin

(Fab.)
August 20... Present report

March 1 to Park, O., 1929

Holmquist, 1928

Park, O., 1929

Holmquist, 1928

Park, O., 1929

Present report

Present report

record...... Burrill and

Smith, 1919

${ }^{2}$ Batrisodes globosus (Lec.) is probably the only species of this genus so far reported from these nests of Formica ulkei. In 1929 I reported that $B$. denticollis Casey was also present, but subsequent study and collection has proven that the latter were all females of the former species. Holmquist (1928) in addition reported the presence of a third species, $B$. spretus Lec. and, although I have not examined this latter material it is possible that this record also refers to females of globosus. Extensive and intensive collecting in these mounds since 1929 has never yielded either $B$. denticollis or $B$. spretus, although $B$. globosus is almost always to be had in numbers. 
TABLE II

\section{Coleoptera reported from nests of Formica exsectoides}

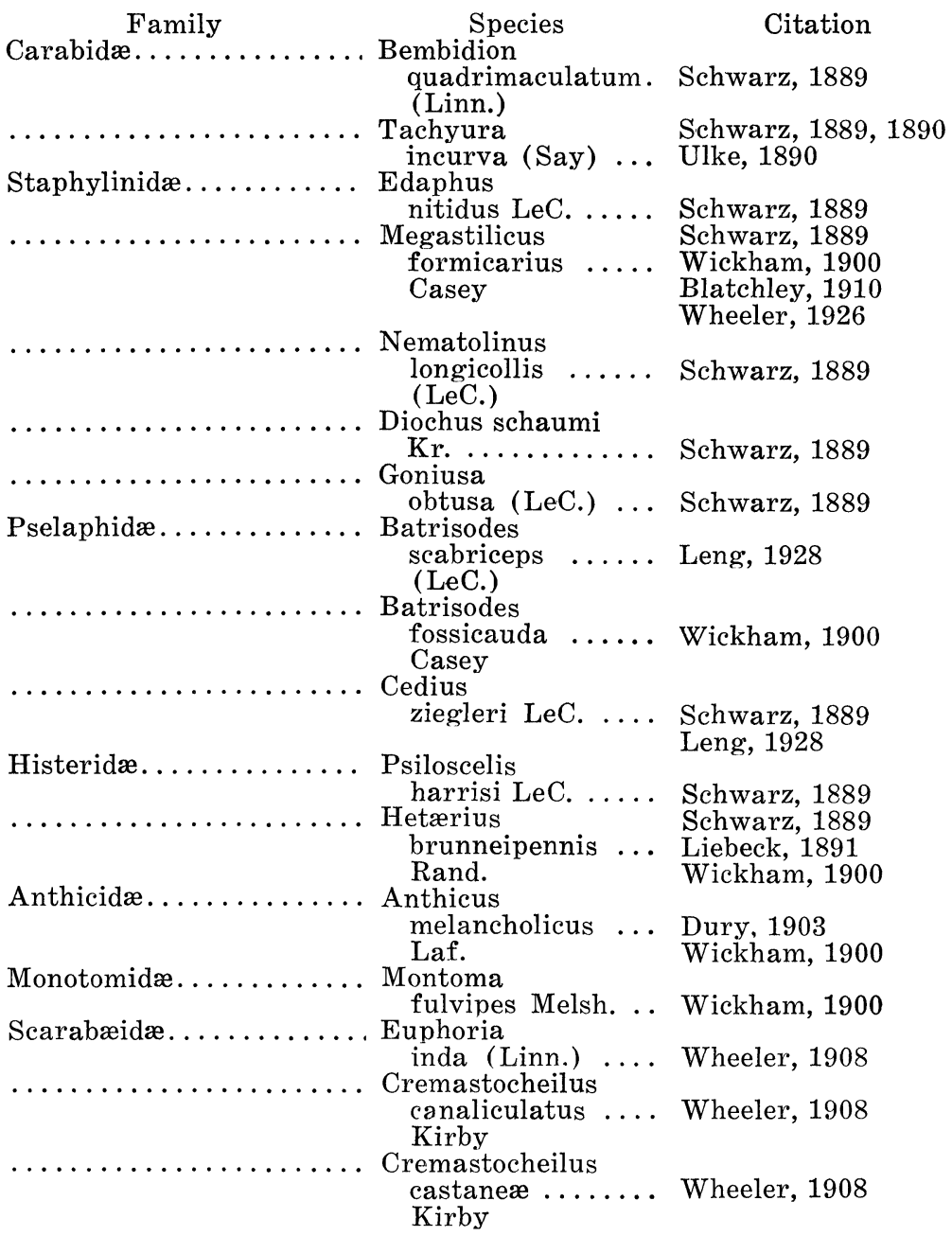


Batrisodes are probably ecologically equivalent. Such identity and parallelism when investigated more fully should further our imperfect understanding of host-guest interrelations within the nest biocoenose.

In such a populous community as a $F$. ulkei nest it is expected that many species stray into the mound, or are taken in by the ants. The cases of Harpalus pleuriticus, Amara polita and Cathartus advena may indicate such accidental circumstance, penetration for purposes of hibernation, or passing the day within the nest in the case of a nocturnal form such as polita. Other species may pass a part of their life cycle in the mounds, either accidentally (Melanotus communis), or habitually (Microdon larvæ). The larvæ and pupæ of Phyllophaga horni and other species not yet determined are rather abundant in the nests. Their presence may or may not be significant, but since many other scarabæids are myrmecocolous, exclusive of the Cremastocheilini, (Riley, 1882; Smith, 1886 ; Schwarz, 1889; Wickham, 1892, 1896 ; Wheeler, 1908, 1926 ; Donisthorpe, 1927) more investigation is needed in the case of the May-beetles.

The presence of the chrysomelid larvæ of Coscinoptera dominicana in the Wisconsin ulkei mounds (Riley, 1882?; Burrill and Smith, 1919) is interesting, and suggests further study since the genus in North America, and in England and Europe related genera, are known to be myrmecocolous in the larval and pupal stages (Riley, 1882; Schwarz, 1896; Wickham, 1898; Wheeler, 1926; Donisthorpe, 1902, 1927).

The single record for Clivinia bipustulata was probably accidental, and the beetle was undoubtedly stimulated by the darkness and moisture of the nest. It is a geocole by habit, burrowing in moist earth and mud margins of streams or marshes, and has been found to be nocturnal (Park and Keller, 1932). When taken, the beetle was a foot beneath the dome of the nest, in wet clay soil with a temperature of $16 \mathrm{C} .^{\circ}$ In a laboratory nest it buried during the day and was not found by the host ants. It was attacked and readily put to flight by such nest predators as Megastilicus formicarius. 
Three of the small phalacrid beetle, Stilbus probatus, ${ }^{4}$ were taken on September 13, 1932, from one part of a deep ulkei gallery, and six more from another nest at a depth of four feet on June 2, 1934. Their presence with ulkei was the only datum obtained, however, the records are of interest.

The small Atheta polita, belonging to a tribe of staphylinids which includes many habitual myrmecocoles, is an all year resident of the ulkei nest. However, little is known concerning it. It is capable of making short evening flights, and in artificial nests easily evades the ants. Its food and ecological position within the nest society are unknown. Although it occurs elsewhere in some abundance, its continual presence with ulkei can hardly be accidental.

The exact status of another staphylinid, Gastrolobium bicolor, is also uncertain. It has been taken twice in the nests. A male and female were obtained on May 7, and a third beetle on August 20,1932. These records are probably accidental since the species is widely distributed over the Chicago Area, where it inhabits moist forest floors and stream margins beneath logs and stones. In the laboratory the beetles avoided the host ants, running away with uplifted abdomens. On the night of May 18 one of the beetles attacked and dismembered and devoured three Batrisodes globosus. Since the latter fills a constant niche in the ulkei society we see the possibilities for disturbing the equilibrium of the biocoenose arising from even accidental penetration by a non-myrmecocolous predator.

The role of Leptinus testaceus ${ }^{5}$ is poorly understood, chiefly due to its presence in such a variety of habitats. It is found within the nests of small forest mammals, bird nests, certain of the social wasps, bees and ants and in isolated log mold, not harboring mammals. Such a list provokes inquiry as to the natural niche of the species, especially in view of the probable ectoparasitism of related

${ }^{4}$ The first lot were collected by the writer, and the second group by Mr. Strohecker. Both lots were independently determined by the writer, and by Mr. Emil Liljeblad of the Field Museum.

5In 1929 the following data were unfortunately omitted. Donisthorpe (1909) records three collectings of Leptinus testaceus with Lasius fuliginosus but states that it is usually taken in nests of bees, birds, moles and small rodents. 
leptinids, and has been discussed elsewhere (Park, 1929). These delicate animals, eyeless, extremely flattened, and of pale yellow color were apparently unmolested by the ulkei workers, but were attacked and devoured by nest predators mentioned later. The food of this species remains uncertain, but as far as its presence with ulkei is concerned, it appears to be a tolerated form, one of the loricate synoeketes.

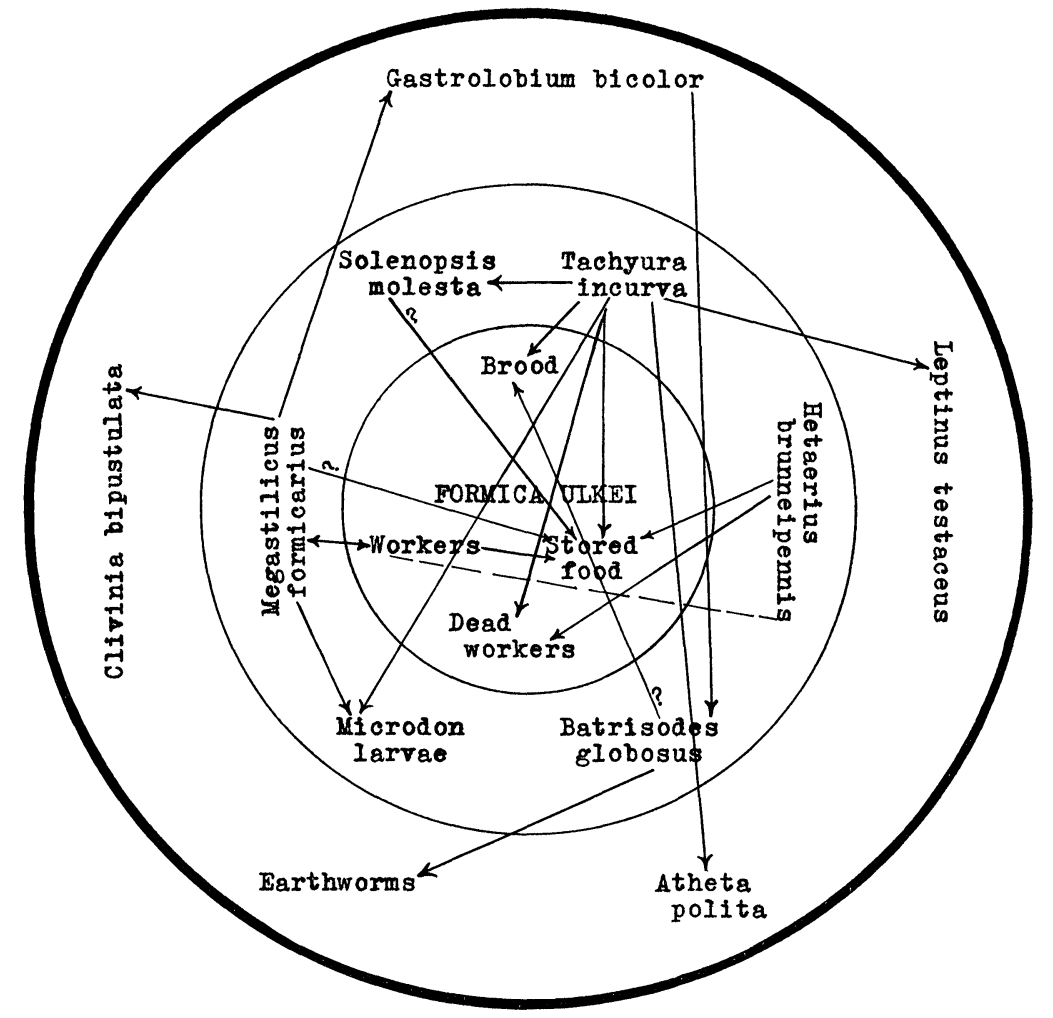

Fig. 1. Diagram of some of the food interrelations among the myrmecocoles of Formica ulkei Emery. The inner circle encloses the host species and its food supply; the intermediate circle contains those species where a definite association is known to exist with the host; the outer circle is reserved for either accidentals or those forms where the relationship is still obscure.

The arrows point to the food and away from the feeder. The broken line indicates regurgitation of food by the host workers. 
The small predaceous carabid, Tachyura incurva, on the other hand, is a year round occupant of the ulkei mounds, and is the most consistently abundant myrmecocole in the nest and trophoporic field. Schwarz (1889) thought the species an accidental visitor of ant nests, but later, with accumulation of data, reversed his opinion (1890).

In the laboratory nests the food of incurva is highly diversified. The beetles feed upon dead or disabled individuals of their own species, dead and disabled host ants, the host brood, and dead insects brought into the nest by the worker ants. In addition, the ulkeicoles are also attacked where the species offers little resistance (Leptinus testaceus, Atheta polita), or are eaten when injured (Microdon larvæ, queens of the lestobiotic guest ant, Solenopsis molesta). Finally, incurva fed upon the sugar water and honey placed in the artificial nests.

The nest conditions are apparently very favorable for the species and its general behavior has been discussed elsewhere (Park, 1929). It appears to be a tolerated form, or at least very successful in avoiding persecution by the host ants. Its catholic feeding habits fit it for the general role of nest scavenger, although it may be strictly predaceous upon occasion.

We now turn to an habitual myrmecocole, the actively persecuted staphylinid, Megastilicus formicarius. It is common in the nests of $F$. exsectoides (Schwarz, 1889; Blatchley, 1910; Wickham, 1900), and Wheeler (1926) discusses the relation of this latter host to the beetle upon (1) the red and black coloration and ant-like appearance of the species, (2) its defensive mechanism, which is similar to that of the related staphylinid Myrmedonia, consisting of emitting a volatile whitish fluid from the raised tip of the flexible abdomen, and (3) that the ants kill the beetle within a few hours when in laboratory nests, but are eluded easily by the beetles in nature. He found formicarius too feeble to kill living exsectoides workers.

Formicarius has been taken repeatedly from the ulkei nests and studied in the laboratory. The above summary of its relations with exsectoides has been found to hold in general for ulkei. However, in the artificial nests of ulkei, formicarius is an agile and wary species. The ants attack 
the beetles whenever the opportunity is presented, but with very indifferent success. When attacked the beetles usually wheel to present the posterior end to the ant and raise the apex of the abdomen. At times the beetle merely crouches, with the head lowered and antennæ pressed back and in to the body, while the abdomen is raised and its apex directed forwards over the sloping elytra. Both maneuvers serve the same purpose, the ant recoiling and behaving as though temporarily stunned. Meanwhile, the beetle escapes.

Infrequently, upon meeting an ant the formicarius would not raise the abdomen but would dodge away and attempt flight, either by running or by crouching and then crawling away between the ant's legs as the ant attempted to bite the beetle. If this retreat was blocked then the abdominal defense was successfully employed.

The worker ulkei almost always attacked these beetles at the slender neck or peduncle between the head and pronotum. Once such a hold was obtained the outcome was more doubtful. I have witnessed such combats where the ant had seized a beetle by the neck and the two struggled back and forth. One of these encounters lasted twentyfive minutes continuously, with the beetle thrusting the apex of its abdomen at the ant's head. At the end of this time the ant still held the beetle's neck between her mandibles, but appeared inert otherwise. The ant's jaws were pried apart and the formicarius ran off, unharmed, but the ant proved to be dead. The same beetle was then examined but the integuments were not even scratched. Of course, the ant may have been an enfeebled individual but we think that it was killed by the beetle's abdominal secretion. The protection of formicarius from ulkei, then, lies in (1) a hard exoskeleton, (2) agility, and (3) a defensive abdominal secretion which, under certain conditions at least, may be lethal.

At times a formicarius would be killed, when placed in a small watch glass with five or six workers. This usually happened during the night, and although the beetle would be dismembered, it was not eaten.

So far Megastilicus formicarius has not been observed to feed on dead host ants, although this is to be expected. 
It does feed upon injured Microdon larvæ, chewing the flesh of wounds and licking the exuding body fluids. It has also been observed to attack and put to flight the larger staphylinid, Gastrolobium bicolor. Formicarius drinks from small pools of water in the artificial nests. In drinking, the head is lowered and the fore-legs spread apart; the water is pushed into the mouth by the maxillæ and labium, while the mandibles are held widely agape and partly immersed in the liquid.

After feeding, formicarius cleans itself elaborately. The vertex is rubbed by the prothoracic tarsi, usually both legs scraping together. The antennæ are cleaned by pushing them between the slightly gaping mandibles from above. The antennæ are then pulled back and forth, usually one at a time, in part by their own activity, but also by the fore-legs which push them upwards. After the antennæ are cleaned they are withdrawn and the prothoracic tarsi and tibiæ are thrust between the jaws, one leg at a time, and drawn back and forth rapidly. The front legs may also be rubbed together, after the manner of so many flies. The left elytron is scraped by the left middle leg and the right elytron by the right middle leg. The dorsal surface and sides of the abdomen are scraped by the metathoracic legs. Finally the wings are unfolded and held so that they parallel the abdomen, and moved from time to time. When the wings are retracted again, this action is aided chiefly by the raised apex of the abdomen.

Another characteristic myrmecocole is the small pselaphid, Batrisodes globosus. It lives all the year round with Formica ulkei as one of its most abundant guests. This beetle, however, is reported with many kinds of ants. Blatchley (1910) records the species "in the large coneshaped nests of ants," which may refer either to ulkei or exsectoides. Schwarz (1889-1890) reported this pselaphid from nests of Camponotus pennsylvanicus, Lasius americanus, and Cremastogaster lineolata; Wickham (1898-1900) found it with Camponotus herculeanus, Lasius americanus, and Lasius aphidicola. Park (1932b) observed it with Lasius americanus, and I can now add the following hosts:

${ }^{6} \mathrm{I}$ am indebted to Dr. Thomas Park and Dr. M. R. Smith for determination of these host ants. 
Springfield, Illinois (April 25) with Lasius americanus; Cambridge, Wisconsin (May 26) with Camponotus noveboracensis; Madison, Wisconsin (May 26) with Lasius americanus. The species, then, is known to have a number of hosts, but is not habitually taken with ants, since it is common in moist, decaying log mold in rich forests throughout the year.

The ulke $i$ workers tolerate this pselaphid in their nests, seldom giving more than a wave of the antennæ when passing a beetle. On their part, the beetles usually walk on when passing a worker, and seldom crouch to the soil. Only once was an ant observed to attack globosus. On this occasion the ant picked up the beetle by surrounding it with her legs, and then attempted to bite it. The beetle however easily escaped, and walked off without the ant giving chase. Although rare, such an incident shows that the host will attack this normally tolerated form.

In 1929 the writer was unable to discover what globosus fed upon in the ulkei nest. Since then further investigation has produced a great deal of information. When globosus is isolated in artificial nests with earthworms, the beetles feed avidly on the latter, biting the worm's integument and eating the slime secreted. Such feeding, when examined under magnification, showed that the pselaphids bit and gnawed the worm's cuticula in the manner of predaceous carabids and staphylinids. They planted their foretarsi upon the worm, bit savagely and then pulled upwards, bracing their legs against the writhing worm. When entangled in the slime, the beetles struggled and eventually freed themselves, extricating one tarsus after another. Wounds made in the worm's body wall were readily attacked, as were also amputated segments placed in the nests. The twisting worms did not deter their feeding, and as many as three pselaphids per square centimeter of earthworm surface have been seen feeding, under laboratory conditions. When one pselaphid approaches another feeding beetle too closely, the latter pauses long enough to bite at the intruder, and usually drives it away.

The pselaphids may feed for thirty minutes. When through eating they clean their antennæ and fore-legs as noted previously for Megastilicus. After cleaning them- 
selves they may or may not resume feeding. Holmquist (1928a) listed two species of earthworms in the ulkei nests, and since these oligochaetes are abundant in the wet soil of the nest rich in organic débris, they may form a part of the normal diet of globosus.

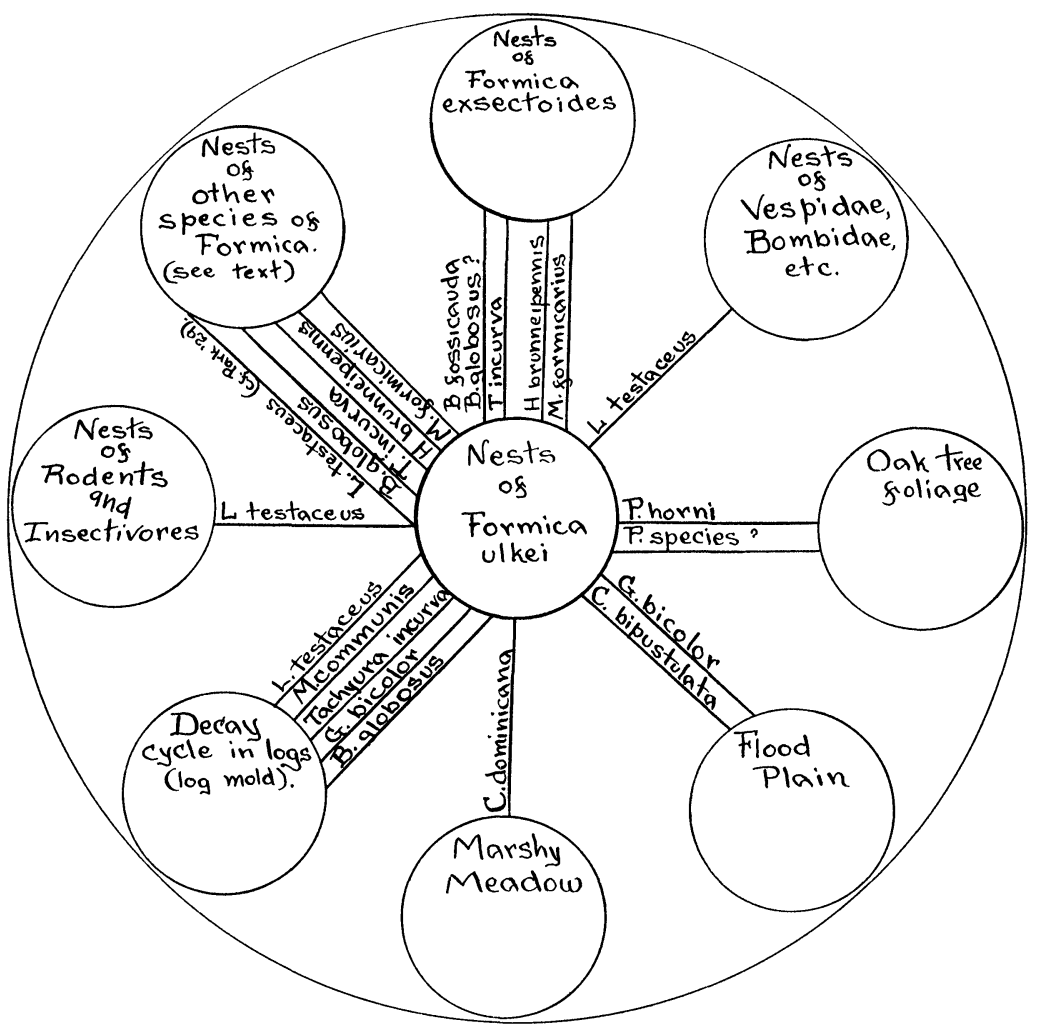

FIG. 2. Diagram of some of the habitat interrelations among the myrmecocoles of Formica ulkei Emery.

When a number of these pselaphids are isolated without food in an artificial nest the first individuals to die are summarily attacked by their cannibalistic companions who bite and lick at the integuments and especially at the articular membranes. From these data it is clear that Batrisodes globosus is a predator, attacking other ulkeicoles, and 
may also act as a nest scavenger. Since this same species has been shown to eat the brood of Lasius americanus (Park, 1932b), it may well attack the young of Formica ulkei.

The last beetle to be discussed is the histerid, Hetærius brunneipennis. The genus Hetærius numbers some twentytwo species, all habitually found with ants. The ecology of most of the species remains unknown but brunneipennis has been well studied (Hamilton, 1888; Schwarz, 1890; Liebeck, 1891; Wickham, 1896, 1900; Wheeler, 1908, 1926). Wheeler assigns the genus to the symphiloid synoeketes (1926) and has given us our only comprehensive study of this species (1908). The following observations were made upon the brunneipennis found with Formica ulkei, and bear out the general conclusions of others concerning this beetle with different host ants.

May 11: a worker ant and one histerid placed in a petri nest at 2:00 P.M. The histerid letisimulated for five minutes and then began walking slowly ahead on the last two pair of legs, rubbing the anterior legs together at the same time. It walked in this manner for thirty minutes, covering twelve centimeters. During this time frequent halts were made to clean the legs and body. The front legs were drawn over the pronotum and head and then pushed slowly through the gaping mandibles. At intervals in its slow progress it would stop and rear up on the extended front legs. At 4:15 P.M. a dead ant was added. The histerid promptly mounted the latter but did not molest it. The living worker ran over to the beetle and licked the glandular area on the right posterior pronotal angle. While the host attended the beetle the latter remained motionless, not even withdrawing its antennæ. At 4:25 the histerid was given a thorough licking by the ant. The latter first licked the beetle's head and mouth parts and while doing so regurgitated a drop of liquid on to the beetle's mandibles. After this prolonged ministration the ant rolled the beetle over and bit twice at the right posterior pronotal angle again. The ant then licked the dorsal and ventral surfaces of the prothorax. This licking, fondling and feeding of the beetle continued for twenty minutes. During this period 
the histerid remained passive with legs and antennæ outstretched.

On the following day the histerid was discovered in the morning gnawing spasmodically on the dead ant's left posterior leg at the femorotibial joint. Through the day this gnawing continued, and by 4:00 P.M. it had chewed free a small strand of the articular membrane and was persistently enlarging the perforation.

This isolated account is typical of the beetle's activities within the laboratory nests, and we conclude that the histerid is thoroughly adjusted to the ulkei biocoenose, where it is attended, cleaned, fed upon regurgitated foods by the worker ants and also eats dead insects in the nest. The workers in return for these many attentions bestowed upon the histerids, seem greatly stimulated by the glandular pronotal areas. This species is the most perfectly adjusted to ulkei of any of the guests so far reported.

Observation of these fifteen species of beetles associated with Formica ulkei show us that the several species eat many things and are in different categories with respect to food competition and adjustment to the host. The complexity of food interrelations for this very imperfectly understood biozoenose is suggested by the diagram in the accompanying figure (Fig. 1).

Another problem involved is the ecological role played by each form in the nest. The position of a species is usually a definite one with respect to its relation with other nest inhabitants, although this status is frequently different in its several life history stages. Our grasp of many of the larger community problems may depend to an unknown degree upon the amount of accurate information we have on the smaller, microhabitats, and therefore a great deal of autecological data must be had before we can really understand a large unit. The following table (Table III) is a tentative arrangement to indicate the role of these fifteen forms in the ulkei nest, the technical terms following the system employed by Wasmann and later modified by Wheeler (1926).

Since many of these species have a facultative role, and consequently occupy both the ulkei nest and other habitat niches, the complexity is greatly increased. These possible habitat interrelations are shown for some of the forms in Fig. 2. 
TABLE III

\section{Ecological Status of Ulkeicoles}

\section{Species}

Status

1. Harpalus pleuriticus ....... Chance occurrence.

2. Amara polita ............ Chance occurrence.

3. Clivinia bipustulata ....... Chance occurrence.

4. Gastrolobium bicolor ....... Chance occurrence.

5. Cathartus advena ......... Chance occurrence.

6. Melanotus communis ...... Pupa. Chance occurrence.

7. Stilbus probatus .......... Status problematical.

8. Phyllophaga horni ........ Facultative larval stage?

9. Coscinoptera dominicana .... Facultative or Habitual larval stage?

10. Megastilicus formicarius .... Habitual Synecthran.

11. Atheta polita ........... Facultative Synecthran or Synoekete?

12. Tachyura incurva ........ Facultative Synoekete.

13. Leptinus testaceus ......... Status problematical:

Facultative Loricate Synoekete.

14. Batrisodes globosus ........ Facultative Mimetic Synoekete.

15. Hetaerius brunneipennis ... Habitual Symphiloid Synoekete.

\section{BIBLIOGRAPHY}

Blatchely, W. S. (1910). Coleoptera known to occur in Indiana. Indianapolis: Nature Pub. Co., $1386 \mathrm{pp}$.

Burrill, A. C. and M. R. Smith (1918). A preliminary list of ants of Wisconsin. Ohio Jour. Sci., 18: 229-32.

(1919). A key to the species of Wisconsin ants, with notes on their habits. Ibid, 19:279-92.

Donisthorpe, H. St. J. K. (1902). The life history of Clythra quadripunctata L. Trans. Ent. Soc. London, 11-23.

(1909). On the origin and ancestral form of myrmecophilous Coleoptera. Ibid, 397-411.

(1927). The guests of British Ants. London: G. Routledge and Sons, $244 \mathrm{pp}$.

Dreyer, W. A. (1932). The effect of hibernation and seasonal variation of temperature on the respiratory exchange of Formica ulkei Emery. Physiol. Zoöl., 5: 301-31.

Dreyer, W. A. and Thomas Park (1933). Local distribution of Formica ulkei mound-nests with reference to certain ecological factors. Psyche, $39: 127-33$.

Dury, Charles (1903). A revised list of the Coleoptera observed near Cincinnati, Ohio. Jour. Cincin. Soc. Nat. Hist., 20:107-96.

Hamilton, John (1888). Catalogue of the myrmecophilous Coleoptera with bibliography and notes. Can. Ent., 20:161-6. 
Holmquist, A. M. (1928a). Notes on the life-history and habits of the mound-building ant, Formica ulkei Emery. Ecology, 9: 70-87. $(1928 \mathrm{~b})$. Studies in arthropod hibernation. II. The hibernation of the ant, Formica ulkei Emery. Physiol. Zoöl., $1: 325-57$.

Leng, C. W. (1928). A list of the insects of New York. Mem. 101, Cornell Univ. Agr. Exp. Sta.

Liebeck, Charles (1891). (Note). Ent. News, 2: 120.

Park, Orlando (1929). Ecological observations upon the myrmecocoles of Formica ulkei, especially Leptinus testaceus Mueller. Psyche, 36: 195-215.

(1930). Studies in the ecology of forest Coleoptera. Seral and seasonal succession of Coleoptera in the Chicago Area, with observations on certain phases of hibernation and aggregation. Ann. Ent. Soc. Am., 23: 57-80.

Coleoptera to . Studies, etc. II. The relation of certain associated with fungi in the Chicago Area. Ecology, 12:188-207. (1932a). The myrmecocoles of Lasius aphidicola Walsh. Ann. Ent. Soc. Am., 25: 77-88.

$(1932 b)$. The food of Batrisodes globosus (Lec.). Jour. N. Y. Ent. Soc. $40: 377-78$.

(1933a). The food and behavior of Tmesiphorus costalis Lec. Ent. News, 44:149-151.

(1933b). Ecological observations upon the Ptiliid myrmecocole, Limulodes paradoxus Matthews. Ann. Ent. Soc. Am., 26: 255-61.

Park, Orlando and J. G. Keller, 1932. Studies in Nocturnal Ecology, II. Preliminary analysis of activity rhythm in nocturnal forest insects. Ecology, 13: 335-46; Errata, Vol. 14.

Park, Thomas (1929). Notes on the relationship between Formica ulkei Emery and Solenopsis molesta Say. Ent. News, 40:325-26.

Riley, C. V. (1882). Habits of Coscinoptera dominicana. Am. Nat., $16: 598$.

Schwarz, E. A. (1889). Myrmecophilous Coleoptera found in Temperate North America. Proc. Ent. Soc. Wash., 1: 237-247.

$3: 73-77$. (1890). (Note). Ibid, 2:88.

(1896). (Note on Coscinoptera dominicana.) Ibid,

Smith, J. B. (1886). Ants'-nests and their inhabitants. Am. Nat., $20: 679-87$.

Ulke, H. (1890). (Note). Proc. Ent. Soc. Wash., $2: 87$.

Wheeler, W. M. (1908). Studies on Myrmecophiles. II. Hetærius. Jour. N. Y. Ent. Soc., 16:135-43.

- (1926). Ants, their structure, development and behavior. New York: Columbia Univ. Press, $663 \mathrm{pp}$.

Wickham, H. F. (1892). Notes on some myrmecophilous Coleoptera. Psyche, 6: 321-23.

72.

(1896). On Coleoptera found with ants. Ibid, $7: 370$ -

21.

(1898). On Coleoptera found with ants. Ibid, 8: 219-

(1900). On Coleoptera found with ants. Ibid, 9:3-5. 

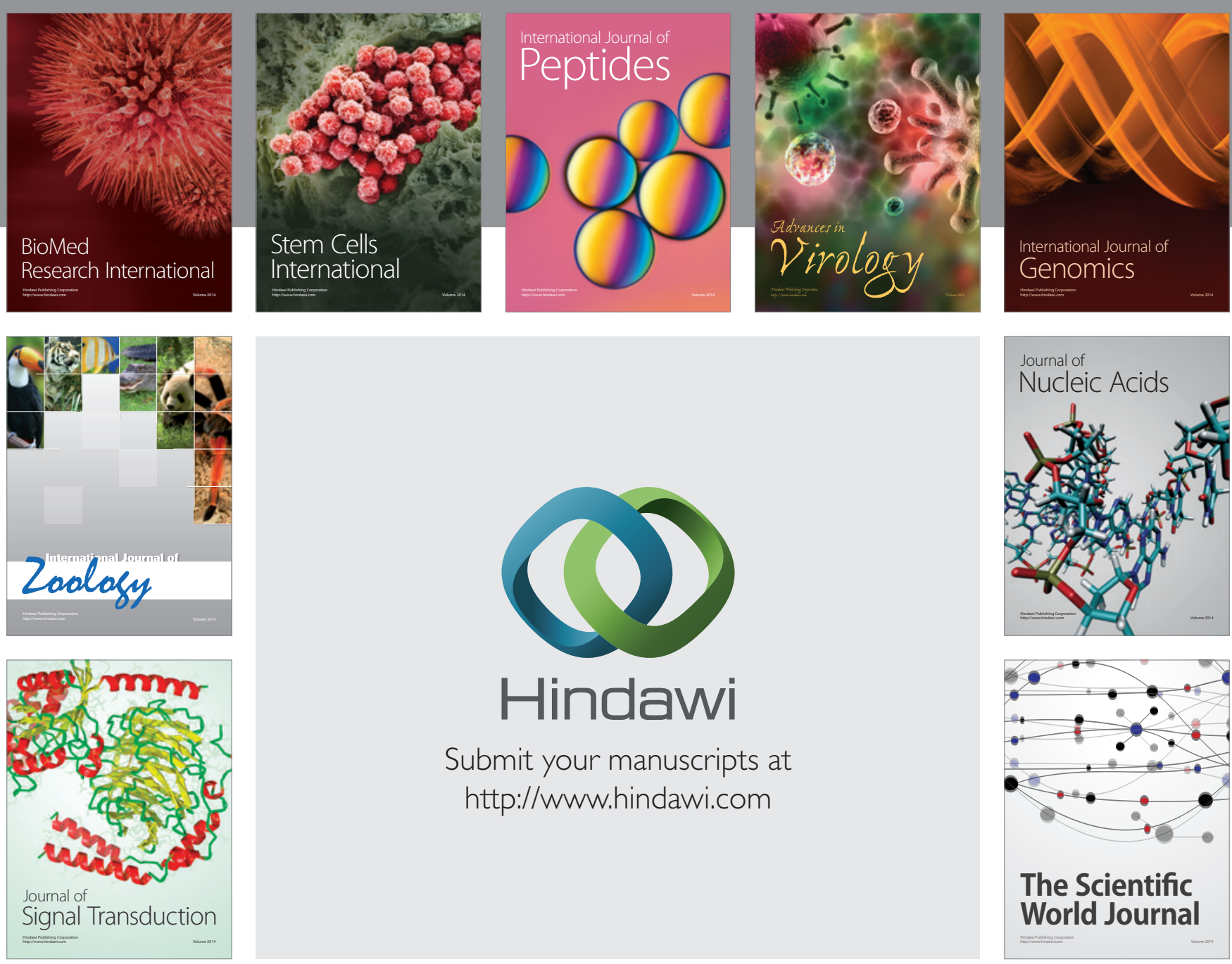

Submit your manuscripts at

http://www.hindawi.com
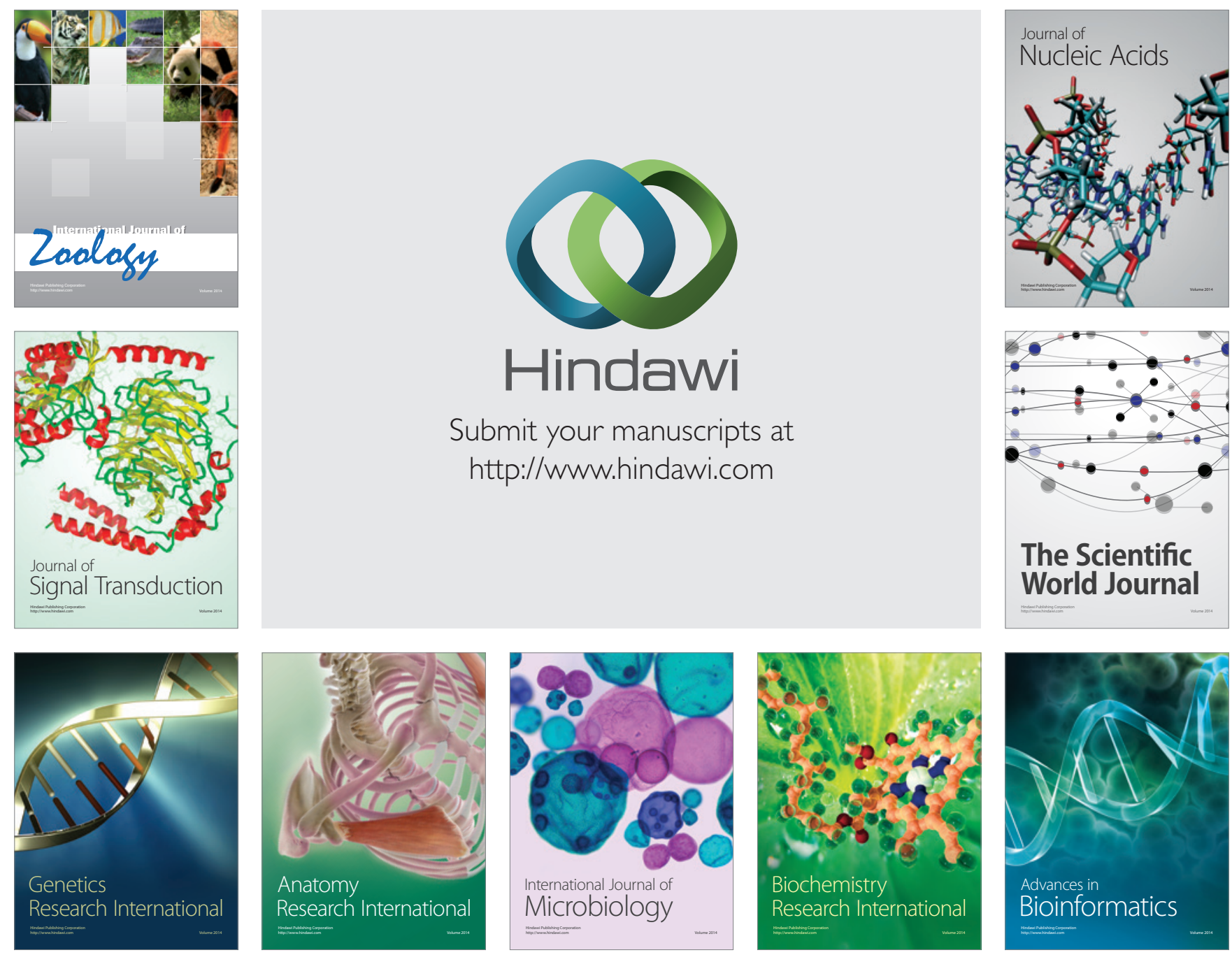

The Scientific World Journal
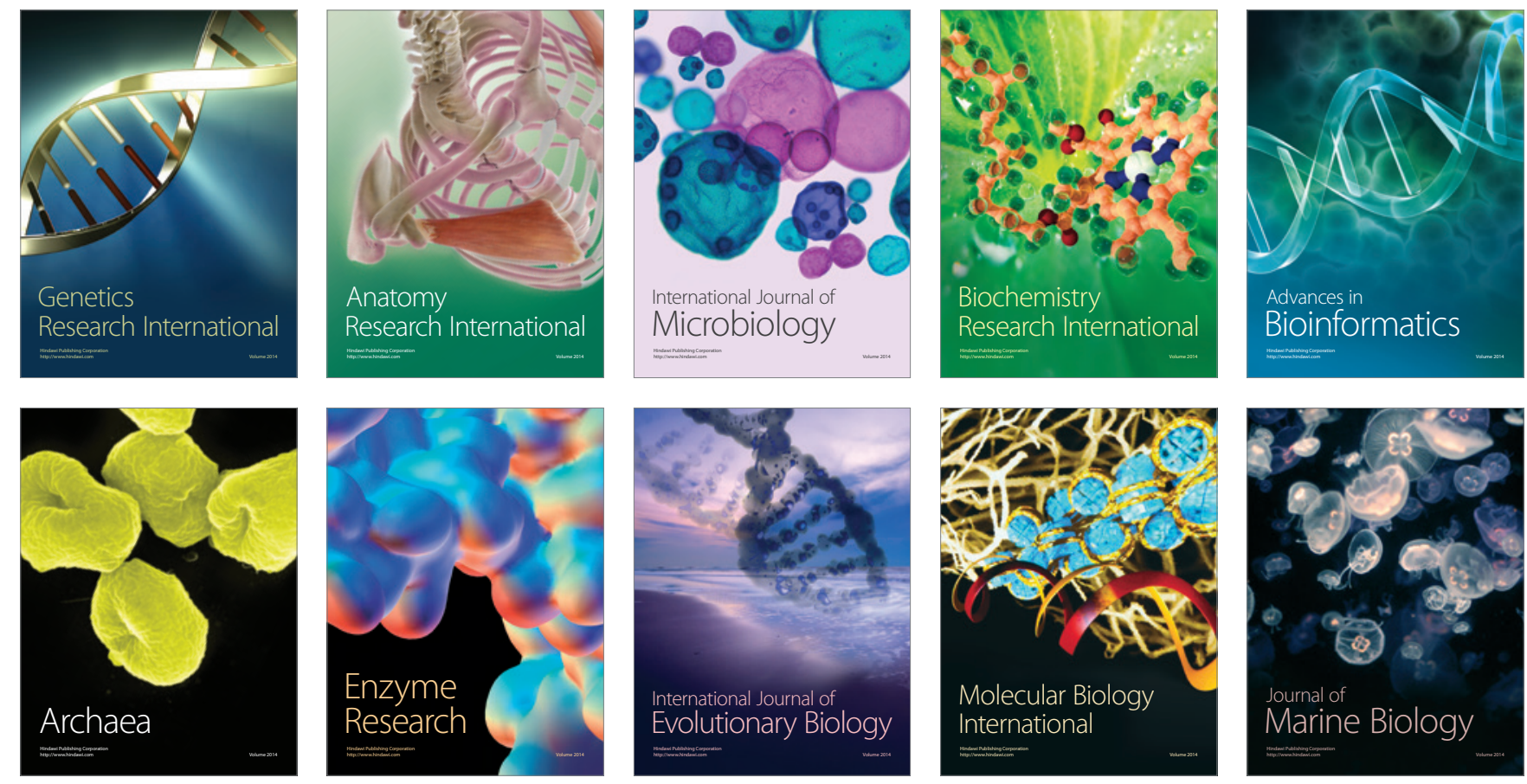